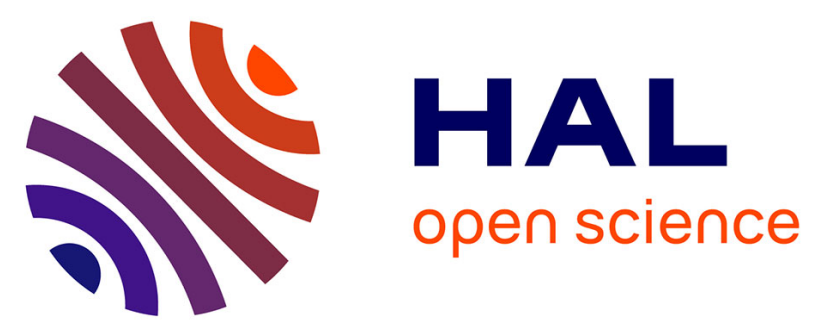

\title{
Combined strategies following surgical drainage for perianal fistulizing Crohn's disease: failure rates and prognostic factors
}

\author{
A. Herissay, Laurent Siproudhis, E. Le Balc'H, A. Merlini L'Heritier, M \\ Dewitte, Timothée Wallenhorst, Guillaume Bouguen, C. Brochard
}

\section{To cite this version:}

A. Herissay, Laurent Siproudhis, E. Le Balc'H, A. Merlini L'Heritier, M Dewitte, et al.. Combined strategies following surgical drainage for perianal fistulizing Crohn's disease: failure rates and prognostic factors. Colorectal Disease, 2021, 23 (1), pp.159-168. 10.1111/codi.15241 . hal-02927333

\section{HAL Id: hal-02927333 \\ https://hal.science/hal-02927333}

Submitted on 11 Sep 2020

HAL is a multi-disciplinary open access archive for the deposit and dissemination of scientific research documents, whether they are published or not. The documents may come from teaching and research institutions in France or abroad, or from public or private research centers.
L'archive ouverte pluridisciplinaire HAL, est destinée au dépôt et à la diffusion de documents scientifiques de niveau recherche, publiés ou non, émanant des établissements d'enseignement et de recherche français ou étrangers, des laboratoires publics ou privés. 
DR CHARLENE BROCHARD (Orcid ID : 0000-0001-7354-6301)

Article type : Original Article

\section{COMBINED STRATEGIES FOLLOWING SURGICAL DRAINAGE FOR PERIANAL} FISTULISING CROHN'S DISEASE: FAILURE RATES AND PROGNOSTIC FACTORS

Auguste HERISSAY MD ${ }^{1}$, Laurent SIPROUDHIS MD, PhD ${ }^{2}$, Eric LE BALC'H MD ${ }^{1}$, Alexandre MERLINI L'HERITIER MD¹, Marie DEWITTE MD¹, Timothée WALLENHORST MD, Guillaume BOUGUEN MD, $\mathrm{PhD}^{2}$, Charlène BROCHARD MD, $\mathrm{PhD}^{2}$

1. CHU Rennes, Univ Rennes, F-35000 Rennes, France

2. CHU Rennes, Univ Rennes, INSERM, CIC1414, Institut NUMECAN (Nutrition Metabolism and Cancer), F-35000 Rennes, France

\section{Correspondence to:}

Dr Charlène Brochard

Service des Maladies de 1'Appareil Digestif

CHU Pontchaillou, 2 rue Henri le Guilloux

35033 Rennes Cedex, FRANCE

Phone: + 33299284317

Fax: + 33299284189

Email address: charlene.brochard@chu-rennes.fr

Conflicts of Interest : LS received lecture fees from Abbvie, Ferring and MSD. LS received consultant fees from Takeda and Ferring. GB received lecture fees from Abbvie, Ferring, MSD, Takeda and Pfizer and consultant fees from Takeda, Janssen. CB received lecture fees from Ipsen. AH, ELB, AML, MD, TW have no conflicts of interest 
Word count (excluding title page, abstract, references, table and figure): 2585 words.

Word count of abstract: 226 words.

Sources of Funding: Takeda, MSD

Specific author contributions: AH: data collection, analysis and writing up the first draft of the paper, LS: patient recruitment, conception, design, analysis,interpretation and drafting the article, ELB, AML, MD, TW: patient recruitment, data collection, revising, GB: patient recruitment, conception, interpretation and revising it critically for important intellectual content, CB : patient recruitment, conception, design, analysis, interpretation and drafting the article

All authors approved the final version of the manuscript. 


\section{ABSTRACT (226/250 words)}

Purpose: The medico-surgical strategy for the treatment of perianal fistulising Crohn's disease following surgical drainage remains challenging and debated. The aims were to describe the failure rate of therapeutic interventions after drainage of the fistula tract and to determine the factors associated with failure to optimize medico-surgical strategies.

Methods: All consecutive patients with perianal fistulising CD who underwent surgical drainage with at least a 12-week follow-up were included. Failure was defined as the occurrence of at least one of the following items: abscess recurrence, purulent discharge from the tract, visible external opening, and further drainage procedure.

Results: One hundred sixty-nine patients were included. The median follow-up was 4.0 years. The cumulative failure rates were $20 \%, 30 \%$ and $36 \%$ at 1,3 and 5 years, respectively. The cumulative failure rates in patients who had sphincter-sparing surgeries or seton removal were significantly higher than those who had a fistulotomy. Anterior fistula $(\mathrm{HR}=2.52$ [1.13-5.61], $\mathrm{p}=0.024)$, supralevator extension $(H R=20.78$ [3.38-127.80], $\mathrm{p}=0.001)$ and the absence or discontinuation of immunosuppressants after anal drainage $(\mathrm{HR}=3.74$ [1.11-12.5], $\mathrm{p}=0.032)$ were significantly associated with failure in the multivariate analysis model.

Conclusions: Combined strategies for perianal fistulising CD lead to failure rate of $36 \%$ at 5 years. Where advisable, fistulotomy may be preferred because it has a lower rate of recurrence. The benefits of immunosuppressants require a dedicated prospective randomized trial.

ClinicalTrials.gov ID: NCT03878498 
What does this paper add to the literature? The failure rate of combined strategies for perianal fistulising $\mathrm{CD}$ is less than 40\%. Fistulotomy should be considered in low fistulas. Immunosuppressants may have an important role in maintaining control of perianal fistulising CD.

Key words: perianal fistulising Crohn's disease, fistulotomy, immunosuppressants

\section{INTRODUCTION}

Perianal Crohn's disease (CD) includes non-fistulising(fissures, ulcers and strictures) and fistulising (fistulas and abscesses) lesions. Perianal disease generally is associated with a more aggressive and disabling CD phenotype $(1,2)$. Moreover, patients with perianal CD complain of anal pain, discharge, faecal incontinence and dyschezia; emotional symptoms and impairment of social and sexual functioning significantly alter their quality of life (3). Perianal fistulising CD is frequent since it occurs either before or after the diagnosis of CD in $14 \%-37 \%$ of cases $(2,4,5)$.

The treatment of perianal fistulising CD remains a challenge in clinical practice. The optimal management of perianal fistulising $\mathrm{CD}$ requires the combination of perianal surgeries with systemic treatments. During the past two decades, tumour necrosis factor antagonists (anti-TNF $\alpha$ ) have revolutionized the approach to treating fistulising $\mathrm{CD}$ that is refractory to standard medications $(6,7)$. At present, anti-TNF $\alpha$ antagonists are recommended as the first line of treatment for perianal fistulising CD (8). However, less than half of patients experience sustained remission after one year of follow-up (9).

Following the initial drainage, the surgical management of perianal fistulising CD remains complex and debated. Several types of surgeries have been proposed to achieve the closure of the fistula, with a focus on sphincter-sparing techniques (SST) (rectal advancement flap (10), glue, plug (11), ligation of the intersphincteric fistula (LIFT), radiofrequency, laser, cell injection strains (12), seton removal or fistulotomy (13). However, these techniques are associated with failure and side effects. 
The aims of this study were (i) to describe the failure rate of therapeutic interventions after drainage of the fistula tract and (ii) to determine the factors associated with failure to optimize the medico-surgical strategies.

\section{PATIENTS AND METHODS}

\section{Patients}

All prospective medical data of patients with perianal CD were recorded between January 2005 and August 2018 in the database namely, fondamentum, and were reviewed. The database fondamentum is secured (nominative access code) with a CNIL (Commission nationale de l'informatique et des libertés) declaration (CNIL $\mathrm{n}^{\circ} 1412467$ ). The database is filled in at consultation, during hospitalization and some items are constrained. The data recorded in a secure database were as follows: sex, height, weight, body mass index (BMI), age and luminal CD phenotype at diagnosis according to the Montreal classification (14), extraintestinal manifestations, smoking habits, past and actual treatments (steroids, immunosuppressants and anti-TNF $\alpha$ ) and past surgical history (anal fistula surgery, ileal and/or colonic surgery and stoma). Immunosuppressants included azathioprine, methotrexate, and 6-mercaptopurine.

For the present study, the inclusion criteria were (i) adult age (i.e., aged over 18 years); (ii) CD diagnosis confirmed on clinical, radiological, endoscopic and/or histologic evidence; (iii) undergone both surgical drainage of anal fistula and SST, seton removal or fistulotomy; and (iv) follow-up of at least 12 months. The exclusion criteria were (i) anal neoplasia, (ii) CD diagnosis uncertain, and (iii) anastomotic fistula or enteroanal fistula. Patients with proctectomy, stoma or permanent loose setons were not analysed (Figure 1). 
The study methodology is detailed in the Supplementary Material. The characteristics of the fistula were assessed on the days of i) surgical drainage(s) and ii) surgery for fistula tract management or iii) seton removal. Anatomical classification of perianal CD according to the Cardiff-Hughes classification (15) was used to classify the tract: supralevator fistula, fistula location (anterior or not/high or low), horseshoe fistula, anovaginal fistula, number of fistula tract(s), inter/trans- or suprasphincteric tract, abscess and associated proctitis. Supralevator fistulas were defined as fistulas with supralevator extension. Complex fistulas were defined as supralevator fistulas, deep trans-sphincteric fistulas, fistulas with abscess or extension with the primary tract anovaginal fistulas or horseshoe fistulas. Rectal inflammation was evaluated by rectoscopy. Additionally, CD activity was assessed with the Harvey-Bradshaw Index (16) (HBI), and perianal CD activity was assessed with the Perianal Disease Activity Index (17) (PDAI).

Therapeutic procedures were recorded between the first surgical drainage and the treatment of the tract, including medical treatments (introduction, optimization, switch of immunosuppressant/biological therapy) and surgeries (fistula drainage, intestinal resection). The Harvey Bradshaw Index (HBI), Cardiff classification and PDAI index were used to identify persistent disease; biologics and immunosuppressants were reviewed and adapted according to tertiary centre consensus and staff. According to the HBI, CD is considered to be in clinical remission with an HBI score below 4, mild to moderately active with an HBI score ranging from 4 to 12 and severely active with an HBI score above 12 (16). The PDAI index and clinical assessment were used to identify fistulas that were insufficiently drained. Collections were surgically drained prior to biologic adaptations.

\section{Therapeutic strategies and follow-up}

Fistula tract management (FTM) was defined by the day of SST or fistulotomy or seton removal. The choice of therapeutic strategy was made by the operator according to the anatomical characteristics of the fistula and the patient's field. SST included rectal flap advancement, ligation of the intersphincteric fistula tract (LIFT), fistula plug, fibrin glue injection, Ovesco clip or radiofrequency ablation. 
The evaluation data in the follow-up were extracted from the clinical database. The following data were recorded: occurrence of an abscess, purulent discharge, external fistulous orifice, and discontinuation of immunosuppressant/biological therapy.

The failure of the procedure (SST or fistulotomy or seton removal) was defined as the occurrence of at least one of the following items: abscess recurrence, purulent discharge from the tract, visible external opening, or drainage surgery (10).

Follow-up was defined as the duration between the day of the visit for fistula tract management and the last visit for patients for whom the procedure failed or the last visit.

\section{Statistical analysis}

Data are expressed as the the median and percentile (interquartile range: $25 \%$ and $75 \%$ ) or as the number and percentage of the cohort. The nonparametric Wilcoxon signed-rank test for continuous variables and nonparametric Pearson or Fisher exact tests for categorical variables were used. The judgement criteria were the occurrence of failure after the fistula tract management. The cumulative probabilities of failure were estimated using the Kaplan-Meier method with $95 \%$ confidence intervals [CIs]. To identify factors associated with failure, a univariate analysis was first performed using the log-rank test. The results are shown as hazard ratios (HRs) with 95\% confidence intervals [CIs]. Statistical analyses were performed using JMP Pro 13.0.0 software (SAS institute).

\section{Ethical considerations}

The study protocol was approved by the Comité de Protection des Personnes du Sud-Ouest et Outre-mer III. ClinicalTrials.gov ID: NCT03878498.

\section{RESULTS}

\section{Study population}

Among 212 CD patients who underwent anal fistulas and/or abscesses drainage over a thirteenyear period, 169 patients underwent SST, fistulotomy or seton removal and were included (Figure

1). The baseline characteristics of the population are depicted in Table 1. Only 10 patients (6\%) 
had obesity $\left(B M I>=30 \mathrm{~kg} / \mathrm{m}^{2}\right)$. The duration of $\mathrm{CD}$ was less than one year at first drainage in $74 / 169$ patients $(44 \%)$, and $31 / 169(18 \%)$ had a past history of anorectal stricture or anal ulceration. Most patients received medical treatment before drainage: 62/169 patients (37\%) were or had been treated with immunosuppressant monotherapy, 20/169 (12\%) were or had been treated with anti-TNF $\alpha$ only and $19 / 169$ (11\%) were or had been treated with combination therapy.

\section{Perianal Crohn's Disease at drainage}

Most had complex fistula tracts (F2) in 136/169 cases (80\%) and 21/107 women (19\%) had a rectovaginal or anovulvar tract. Most had an abscess at drainage (107/169, 63\%). Supralevator extension of anal fistula was reported in 66/169 patients (39\%), and a horseshoe fistula was reported in $17 / 169$ patients $(10 \%)$. Overall, 46/169 patients $(27 \%)$ had proctitis. Patients had a median HBI of 5 [3-9] and a median PDAI of 10 [7-12] at drainage.

\section{Management between drainage and fistula tract management}

A total of $24 / 169$ patients (14\%) experienced at least 2 fistula drainages, including 5 (3\%) who underwent at least 3 fistula drainages (including the first drainage) between the first drainage and the fistula tract management. Most patients underwent fewer than 2 surgical procedures for fistula drainage $(145 / 169,86 \%)$.

The drainage of anal fistula induced a change in Crohn's treatments for 137/169 patients (81\%): focusing on biologics, anti TNF alpha was introduced in 84/169 (50\%), and immunosuppressants were introduced in 93/169 (55\%). Anti-TNF alpha was switched or optimized in 13/122 (10\%) patients between drainage and fistula tract management.

\section{Fistula tract management}

The median duration between drainage and fistula tract management was 7.1 [4.2-12.0] months. A description of the fistula characteristics and medical treatments for fistula tract management is shown in Table 2 . Half of the patients $(84 / 169$ cases $(50 \%))$ had high and/or complex fistula tracts (F2). Nineteen/107 women (18\%) had a rectovaginal or anovulvar tract. Supralevator extension of anal fistula was reported in 12/169 patients (7\%), and a high trans-sphincteric fistula was reported in 74/169 patients (44\%). No patient had anal abscess, anal ulceration or proctitis. At fistula tract management, $77 / 169$ patients (45\%) received anti-TNF alpha, and 63/169 (38\%) received 
immunosuppressants. However, only 36/169 (21\%) had combination therapy, and 65/169 (38\%) had neither anti-TNF alpha nor immunosuppressants.

Surgical strategies for fistula tract management are detailed in Figure 1: 61 (36\%) patients underwent a fistulotomy, $64(38 \%)$ patients underwent an SST, and the seton was removed in only $44(26 \%)$ patients. Among the 64 patients who underwent SST, 24 had rectal flap advancement (38\%), 21 (33\%) had glue, 11 (17\%) had plug, 4 (6\%) had radiofrequency ablation, 3 (5\%) had LIFT and $1(1 \%)$ had an Ovesco clip. Surgical strategies according to fistula characteristics at fistula tract management are detailed in Supplementary Material Table 1. Among patients who had a fistulotomy, none had a high or F2 fistula and none had a supralevator extension; all 9 patients who had an anterior fistula and fistulotomy were male. Patients with a high fistula or with supralevator extension preferentially had SST rather than seton removal (50/73 vs 23/73, $\mathrm{p}=0.005$ and $12 / 12$ vs $0 / 12, p=0.0002$ ) compared to those with direct and/or low fistula.

\section{Follow-up}

After a median follow-up period of 4.0 years [1.3-7.2], 55/169 (33\%) patients were in failure. The failure rate is quantified and illustrated in Figure 2. The cumulative failure rates were 20 [16$26] \%, 26[21-33] \%, 30[24-37] \%, 33[27-41] \%$ and $36[29-44] \%$ at $1,2,3,4$ and 5 years, respectively. Actuarial failure curves with respect to surgical options are illustrated in Figure 3. The cumulative failure rates in patients who had an SST were significantly higher than in those who had a fistulotomy: 25 [15-37] \%, 32 [22-43] \%, 36 [26-48]\%, 40 [27-41]\% and 43 [31-55]\% vs $13[7-22] \%, 17[10-27] \%, 20[12-31] \%, 23[14-34] \%$ and $24[15-37] \%$ at $1,2,3,4$ and 5 years, respectively, $p=0.046$ (Figure 3A). The cumulative failure rates in patients who had a seton removal were $24[15-37] \%, 31[20-45] \%, 36[23-51] \%, 40[26-55] \%$ and $43[28-59] \%$ at 1, 2, 3, 4

and 5 years, respectively. These rates tended to be higher than those of patients who had a fistulotomy $(p=0.075)$ (Figure 3B) and were comparable to those of patients who had SST $(p=0.900)$ (Figure 3C). The cumulative failure rates according to the surgical option are detailed in Supplementary material Table 2.

\section{Factors associated with treatment failure}

Figure 4 and Table 3 illustrate items significantly associated with higher failure rates (univariate analyses; $p<0.1)$, including the absence of ulceration $(\mathrm{p}=0.082)$, ileal and/or colonic resection $(\mathrm{p}=0.060)$, the need for at least 2 fistula drainages $(\mathrm{p}=0.0009)$, anterior fistula $(\mathrm{p}=0.047)$, 
supralevator extension fistula tract management $(p=0.0001)$ and the absence/discontinuation of immunosuppressants after fistula tract management $(\mathrm{p}=0.037)$. In contrast, Montreal classification, gender, smoking, fistula characteristics at drainage, medical treatments at drainage and medical treatment modifications between drainage and fistula tract management tract management showed no impact.

Anterior fistula $(\mathrm{HR}=2.52[1.13-5.61], \mathrm{p}=0.024)$ or supralevator extension $(\mathrm{HR}=20.78[3.38$ 127.80] $\mathrm{p}=0.001$ ) at fistula tract management and the absence/discontinuation of immunosuppressants after fistula tract management $(\mathrm{HR}=3.74$ [1.11-12.5], $\mathrm{p}=0.032)$ were significantly associated with higher failure rate in the multivariate analysis model (Table 3 ).

\section{DISCUSSION}

The present work quantified the rate of failure of fistula tract management and assessed the factors associated with failure in perianal fistulising CD. Approximately one-third of patients failed to maintain a sustained benefit. Analyses showed that anterior fistula, supralevator extension and the absence/discontinuation of immunosuppressants after fistula tract management were significantly associated with a less favourable outcome. Fistulotomy was a therapeutic strategy that significantly increased the sustained healing rate.

The main strengths of this work are the sample size, the systematic assessment of perianal CD in a referral centre for $\mathrm{CD}$ and the duration of the follow-up. The data were recorded in a prospective database using recommended classifications and validated scales (16-18). Disease characteristics of $\mathrm{CD}$ and perianal $\mathrm{CD}$ and both medical and surgical strategies were assessed. All events were prospectively recorded. The main judgement criterion was based on failure because it is easier to evaluate and is absolutely objective.

However, our study results should be interpreted with caution for several reasons. The data were prospectively recorded but the analysis was retrospective. The recruitment of patients might have resulted in selection bias: this study was performed in a tertiary referral centre, the number of patients treated with anti-TNF $\alpha$ was high and fistulas were severe. Magnetic resonance imaging (MRI) and systematic assessment of faecal continence were not done for all consecutive patients so these data could not be analysed. Finally, patients with stoma or permanent loose seton were 
not included since we have analyzed the failure rate of therapeutic interventions after drainage of the fistula tract. The stoma and permanent loose seton may be transient but may also be associated with an unfavourable outcome: it may have led to an underestimation of the failure rate.

One of our objectives was to compare the rate of failure of management of drained fistulas. Overall, the failure rate was $30 \%$ at 3 years, which is in accordance with the data in the literature $(6,9)$. It appears that patients who had an SST or seton removal have a nearly 2-fold risk of failure compared to those who have a fistulotomy. This risk is comparable in the short and long term. These data are in line with previous reports $(19,20)$. Some words of caution are needed. Indeed, fistulotomy was performed only when fistulas were simple. Fistulas can be considered simple, even in the case of $\mathrm{CD}$, in case of single fistulas, unbranched, with low tract and without supralevator extension to avoid continence disorders. If these conditions are met, fistulotomy may be an option with respect to the continence status and risk of incontinence.

Importantly, anatomical features of the anal fistula including anterior fistula and supralevator extension negatively impacted the outcome of perianal fistulising $\mathrm{CD}$. These data are in line with previous studies (21). Some anatomical features of fistula can be modified by surgical drainage techniques and lowering of the tract. The goals of fistula surgery are to achieve efficient drainage and simplify fistula tracts. Lowering the tract is an important strategy in managing high/complex fistulas. Therefore, effective fistula drainage which may include several interventions is needed to avoid SST failure in particular rectal flap advancement (10). Furthermore, luminal disease was controlled and no patient had active proctitis. The failure rate of supralevator extension is so high that a complementary strategy including seton removal is questionable. Loose seton could be preferred to avoid abscess recurrence in such a situation.

In contrast to previous works $(7,9)$, this study does not show an association between introduction or adaptation of anti-TNF $\alpha$ and a better healing rate. One hypothesis may be that the modalities of anti-TNF $\alpha$ treatment were heterogeneous due to the retrospective cohort (no long-term treatment and fewer combination therapies at the beginning of the study period). Another hypothesis may be that most patients underwent both surgical and biologic treatments concomitantly as compared with previous studies. Nevertheless, the absence/discontinuation of immunosuppressants after fistula tract management was significantly associated with a less favourable outcome. These data are in accordance with some studies (22-24) suggesting that immunosuppressants would be 
effective in perianal fistulising CD. Medical treatment remains essential to maintain the healing of perianal fistulising $\mathrm{CD}$; this work put into question whether immunosuppressants should be maintained.

Prospective evaluation of faecal incontinence with validated questionnaires is needed to better quantify the benefit/risk ratio of the surgical strategy with a special focus on fistulotomy.

\section{CONCLUSION}

Combined surgical and medical strategies after surgical drainage in perianal fistulising CD lead to failure rate of $36 \%$ at 5 years. Fistulotomy is effective in treating perianal fistulising CD in a lowrisk situations of incontinence; this option should not always be ruled out in principle. Immunosuppressants may have an important role in maintaining control of perianal fistulising CD.

\section{REFERENCES}

1. Ingle SB, Loftus EV. The natural history of perianal Crohn's disease. Dig Liver Dis Off J Ital Soc Gastroenterol Ital Assoc Study Liver. 2007;39:963-9.

2. Schwartz DA, Loftus EV, Tremaine WJ, Panaccione R, Harmsen WS, Zinsmeister AR, et

al. The natural history of fistulizing Crohn's disease in Olmsted County, Minnesota. Gastroenterology. 2002;122:875-80.

3. Mahadev S, Young JM, Selby W, Solomon MJ. Quality of life in perianal Crohn's disease: what do patients consider important? Dis Colon Rectum. 2011;54:579-85.

4. Tang LY, Rawsthorne P, Bernstein CN. Are perineal and luminal fistulas associated in Crohn's disease? A population-based study. Clin Gastroenterol Hepatol Off Clin Pract J Am Gastroenterol Assoc. 2006;4:1130-4.

5. Lapidus A. Crohn's disease in Stockholm County during 1990-2001: an epidemiological update. World J Gastroenterol. 2006;12:75-81.

6. Bouguen G, Siproudhis L, Gizard E, Wallenhorst T, Billioud V, Bretagne J-F, et al. Longterm outcome of perianal fistulizing Crohn's disease treated with infliximab. Clin Gastroenterol Hepatol Off Clin Pract J Am Gastroenterol Assoc. 2013;11:975-981.e1-4. 
7. Present DH, Rutgeerts P, Targan S, Hanauer SB, Mayer L, van Hogezand RA, et al. Infliximab for the treatment of fistulas in patients with Crohn's disease. N Engl J Med. 1999;340:1398-405.

8. Gecse KB, Bemelman W, Kamm MA, Stoker J, Khanna R, Ng SC, et al. A global consensus on the classification, diagnosis and multidisciplinary treatment of perianal fistulising Crohn's disease. Gut. 2014;63:1381-92.

9. Sands BE, Anderson FH, Bernstein CN, Chey WY, Feagan BG, Fedorak RN, et al. Infliximab maintenance therapy for fistulizing Crohn's disease. N Engl J Med. 2004;350:876-85. 10. Bessi G, Siproudhis L, Merlini l'Héritier A, Wallenhorst T, Le Balc'h E, Bouguen G, et al. Advancement flap procedure in Crohn and non-Crohn perineal fistulas: a simple surgical approach. Colorectal Dis Off J Assoc Coloproctology G B Irel. 2019;21:66-72.

11. Senéjoux A, Siproudhis L, Abramowitz L, Munoz-Bongrand N, Desseaux K, Bouguen G, et al. Fistula Plug in Fistulising Ano-Perineal Crohn's Disease: a Randomised Controlled Trial. J Crohns Colitis. 2016;10:141-8.

12. Panés J, García-Olmo D, Van Assche G, Colombel JF, Reinisch W, Baumgart DC, et al. Long-term Efficacy and Safety of Stem Cell Therapy (Cx601) for Complex Perianal Fistulas in Patients With Crohn's Disease. Gastroenterology. 2018;154:1334-1342.e4.

13. Bouchard D, Brochard C, Vinson-Bonnet B, Staumont G, Abramowitz L, Benfredj P, et al. How to manage anal ulcerations and anorectal stenosis in Crohn's disease: algorithm-based decision making : French National Working Group Consensus 2018. Tech Coloproctology. 2019;23:353-60.

14. Satsangi J, Silverberg MS, Vermeire S, Colombel J-F. The Montreal classification of inflammatory bowel disease: controversies, consensus, and implications. Gut. 2006;55:749-53. 15. Hughes LE. Clinical classification of perianal Crohn's disease. Dis Colon Rectum. 1992;35:928-32.

16. Harvey RF, Bradshaw JM. A simple index of Crohn's-disease activity. Lancet Lond Engl.1980;1:514.

17. Irvine EJ. Usual therapy improves perianal Crohn's disease as measured by a new disease activity index. McMaster IBD Study Group. J Clin Gastroenterol. 1995;20:27-32.

18. Satsangi J, Silverberg MS, Vermeire S, Colombel J-F. The Montreal classification of inflammatory bowel disease: controversies, consensus, and implications. Gut. 2006;55:749-53. 
19. Williams JG, Rothenberger DA, Nemer FD, Goldberg SM. Fistula-in-ano in Crohn's disease. Results of aggressive surgical treatment. Dis Colon Rectum. 1991;34:378-84.

20. Papaconstantinou I, Kontis E, Koutoulidis V, Mantzaris G, Vassiliou I. Surgical Management of Fistula-in-ano Among Patients With Crohn's Disease: Analysis of Outcomes After Fistulotomy or Seton Placement-Single-Center Experience. Scand J Surg SJS Off Organ Finn Surg Soc Scand Surg Soc. 2017;106:211-5.

21. Brochard C, Landemaine A, L'Heritier AM, Dewitte MP, Tchoundjeu B, Rohou T, et al. Anal Fistulas in Severe Perineal Crohn's Disease: Mri Assessment in the Determination of LongTerm Healing Rates. Inflamm Bowel Dis. 2018;24:1612-8.

22. Schröder O, Blumenstein I, Schulte-Bockholt A, Stein J. Combining infliximab and methotrexate in fistulizing Crohn's disease resistant or intolerant to azathioprine. Aliment Pharmacol Ther. févr 2004;19:295-301.

23. Roumeguère $P$, Bouchard D, Pigot F, Castinel A, Juguet F, Gaye D, et al. Combined approach with infliximab, surgery, and methotrexate in severe fistulizing anoperineal Crohn's disease: results from a prospective study. Inflamm Bowel Dis. 2011;17:69-76.

24. Topstad DR, Panaccione R, Heine JA, Johnson DRE, MacLean AR, Buie WD. Combined seton placement, infliximab infusion, and maintenance immunosuppressives improve healing rate in fistulizing anorectal Crohn's disease: a single center experience. Dis Colon Rectum. 2003;46:577-83. 


\begin{tabular}{|c|c|}
\hline n (\%) or median [IQR 25-75] & $\begin{array}{c}\text { Global population } \\
\text { N=169 }\end{array}$ \\
\hline $\operatorname{Sex}(\mathrm{M} / \mathrm{F})$ & $62 / 107(37 / 63)$ \\
\hline Age (years) & 32 [24-42] \\
\hline BMI & $22[20-26]$ \\
\hline \multicolumn{2}{|l|}{ Smoking } \\
\hline - Smoker & $53(31)$ \\
\hline - Former smoker & $32(19)$ \\
\hline - No smoker & $84(50)$ \\
\hline Past history of pregnancy \# & $58(54)$ \\
\hline \multicolumn{2}{|l|}{ Characteristics of CD } \\
\hline Duration of Crohn's disease (months) & $20[0-98]$ \\
\hline \multicolumn{2}{|l|}{ Montreal Classification } \\
\hline $\mathrm{A} 1<16$ & $20(12)$ \\
\hline $\mathrm{A} 2<40$ & $128(76)$ \\
\hline $\mathrm{A} 3 \geq 40$ & $21(12)$ \\
\hline L1 & $28(16)$ \\
\hline L2 & $54(32)$ \\
\hline L3 & $83(49)$ \\
\hline B2- stricturing & $42(25)$ \\
\hline Extra-intestinal manifestations & $45(27)$ \\
\hline \multicolumn{2}{|l|}{ Prior treatments before drainage } \\
\hline Ileal and/or colonic resection & $37(22)$ \\
\hline Medical treatment & $133(79)$ \\
\hline Steroids & $103(69)$ \\
\hline Anti-TNF $\alpha$ & $38(23)$ \\
\hline Immunosuppressant (AZA or MTX or 6MP) & $81(48)$ \\
\hline \multicolumn{2}{|l|}{ Perianal Crohn's Disease at drainage } \\
\hline Duration of anal fistula (months) & $2[0-26]$ \\
\hline Cardiff classification & \\
\hline Stricture (yes) & $31(18)$ \\
\hline Ulceration (yes) & $94(56)$ \\
\hline Fistula F2 (yes) & $136(80)$ \\
\hline Horseshoe (yes) & $17(11)$ \\
\hline Recto/ano vaginal fistula (yes) \# & $21(19)$ \\
\hline Supralevator extension (yes) & $66(39)$ \\
\hline \multicolumn{2}{|c|}{$\begin{array}{l}\text { Abbreviations: } \mathrm{BMI}=\text { Body Mass Index, } \mathrm{CD}=\mathrm{Crohn} \text { 's disease, } \mathrm{TNF} \alpha=\text { Tumour Necrosis Factor } \alpha \text {, } \\
\mathrm{AZA}=\text { azathioprine, } \mathrm{MTX}=\text { methotrexate, } 6 \mathrm{MP}=6 \text { mercaptopurine, } \mathrm{IQR}=\mathrm{I} . \mathrm{Q} . \mathrm{R} \text {. for interquartile } \\
\text { range: } 25 \% \text { and } 75 \%) . \mathrm{A}=\mathrm{Age} ; \mathrm{L} 1=\mathrm{ileal}, \mathrm{L} 2=\text { colonic, } \mathrm{L} 3=\mathrm{ileo-colonic} \\
\# \text { of women }\end{array}$} \\
\hline
\end{tabular}




\begin{tabular}{|l|c|}
\hline Table 2: Characteristics at fistula tract management (FTM) and follow-up \\
\hline n (\%) or median [IQR 25-75] & $\begin{array}{c}\text { Global population } \\
\text { N=169 }\end{array}$ \\
\hline $\begin{array}{l}\text { At fistula tract management (FTM) } \\
\text { Anoperianal characteristics } \\
\quad \text { Fistula F2 (yes) }\end{array}$ \\
$\begin{array}{l}\text { Recto/ano vaginal fistula (yes) \# } \\
\text { Transsphincteric high }\end{array}$ \\
$\begin{array}{l}\text { Supralevator extension } \\
\text { Anterior }\end{array}$ \\
$\begin{array}{l}\text { Medical treatment } \\
\text { Anti-TNF } \alpha\end{array}$ & $84(50)$ \\
Immunosuppressant (AZA or MTX or 6MP) & $73(18)$ \\
Combination therapy & $12(7)$ \\
\hline After FTM & $63(37)$ \\
No/Continuation/Discontinuation of anti-TNF & $77(45)$ \\
Duration between introduction and discontinuation events (years) & $63(38)$ \\
& $36(21)$ \\
No/Continuation/Discontinuation of immunosuppressants & $92(54) / 52(31) / 25(15)$ \\
Duration between introduction and discontinuation events (years) & $1.4[0.7-2.8]$ \\
\hline
\end{tabular}




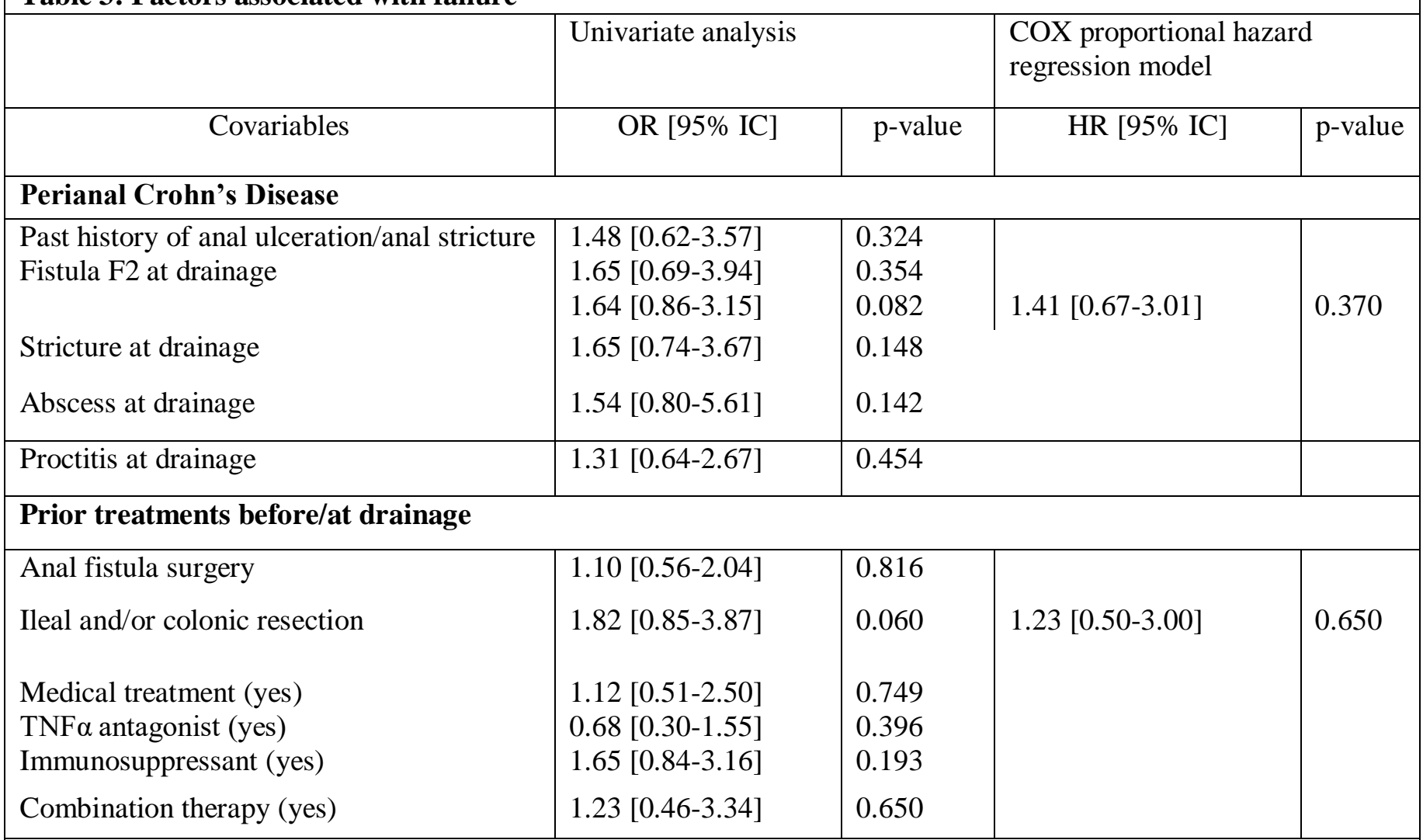

\section{Treatments between/at drainage and fistula tract management}

\begin{tabular}{|c|c|c|c|c|}
\hline Seton (yes) & $1.84[0.70-4.87]$ & 0.336 & & \\
\hline$>=2$ drainages & $2.89[1.20-6.98]$ & 0.0009 & $2.41[0.90-6.43]$ & 0.081 \\
\hline TNF antagonists & & & & \\
\hline Introduction & $0.78[0.41-1.51]$ & 0.538 & & \\
\hline Switch & $0.42[0.13-1.36]$ & 0.106 & & \\
\hline Immunosuppressant (introduction) & $0.66[0.34-1.28]$ & 0.224 & & \\
\hline \multicolumn{5}{|c|}{ Fistula characteristics at fistula tract management } \\
\hline Fistula F2 & $1.66[0.86-3.17]$ & 0.218 & & \\
\hline Anterior fistula & $2.23[0.93-5.32]$ & 0.047 & $2.52[1.13-5.61]$ & 0.022 \\
\hline High fistula & $1.37[0.72-2.63]$ & 0.503 & & \\
\hline Supralevator extension & $12.44[2.62-59.05]$ & 0.0001 & $20.78[3.38-127.80]$ & 0.001 \\
\hline \multicolumn{5}{|c|}{ Treatments at fistula tract management and follow-up } \\
\hline Fistulotomy/SST/Seton removal & - & 0.106 & - & 0.886 \\
\hline Anti - TNF $\alpha$ & $0.59[0.27-1.32]$ & 0.224 & & \\
\hline Immunosuppressants & $0.78[0.33-1.86]$ & 0.607 & & \\
\hline Combotherapy & $0.63[0.27-1.45]$ & 0.260 & & \\
\hline $\begin{array}{l}\text { Absence or discontinuation of } \\
\text { immunosuppressants }\end{array}$ & $2.95[1.07-8.18]$ & 0.037 & $3.74[1.11-12.5]$ & 0.032 \\
\hline
\end{tabular}

Abbreviations : $\mathrm{SST}=\mathrm{CD}=$ Crohn's Disease, Index, IQR= = I.Q.R. for Inter-Quartile Range: $25 \%$ and $75 \%, \mathrm{TNF} \alpha=$ Tumour Necrosis Factor $\alpha$ 


\section{Figure Legends:}

Figure 1: Flowchart of the study population

Figure 2: The cumulative failure rates of Crohn's patients with anoperianal fistulas were 20 [16-26]\%, $26[21-33] \%, 30[24-37] \%, 33[27-41] \%$ and 36 [29-44]\% at 1, 2, 3, 4 and 5 years, respectively.

Figure 3: Failure rates according to the treatment option. Patients who had fistulotomy had less failure than those who had sphincter sparing technique (SST) (A) and tended to have less failure than those who had seton removal (B). The failure rates of patients who had seton removal or SST were comparable (C).

Figure 4 : Items that were associated with significantly higher failure rates (univariate analyses; $p$ $<0.1$ ), including the absence of ulceration (A), ileal and/or colonic resection $(\mathbf{B})$, the need for at least 2 fistula drainages $(\mathbf{C})$, anterior fistula (D), supralevator extension fistula tract management $(\mathbf{E})$ and the absence/discontinuation of immunosuppressants after tract fistula management $(\mathbf{F})$.

\section{Supplementary material:}

(1) Figure : Description of the study methodology

(2) Supplementary material Table 1: Fistula characteristics at fistula tract management according to therapeutic strategy

(3) Supplementary material Table 2: Failure rates according to the surgical option 


\section{FIGURE 1}

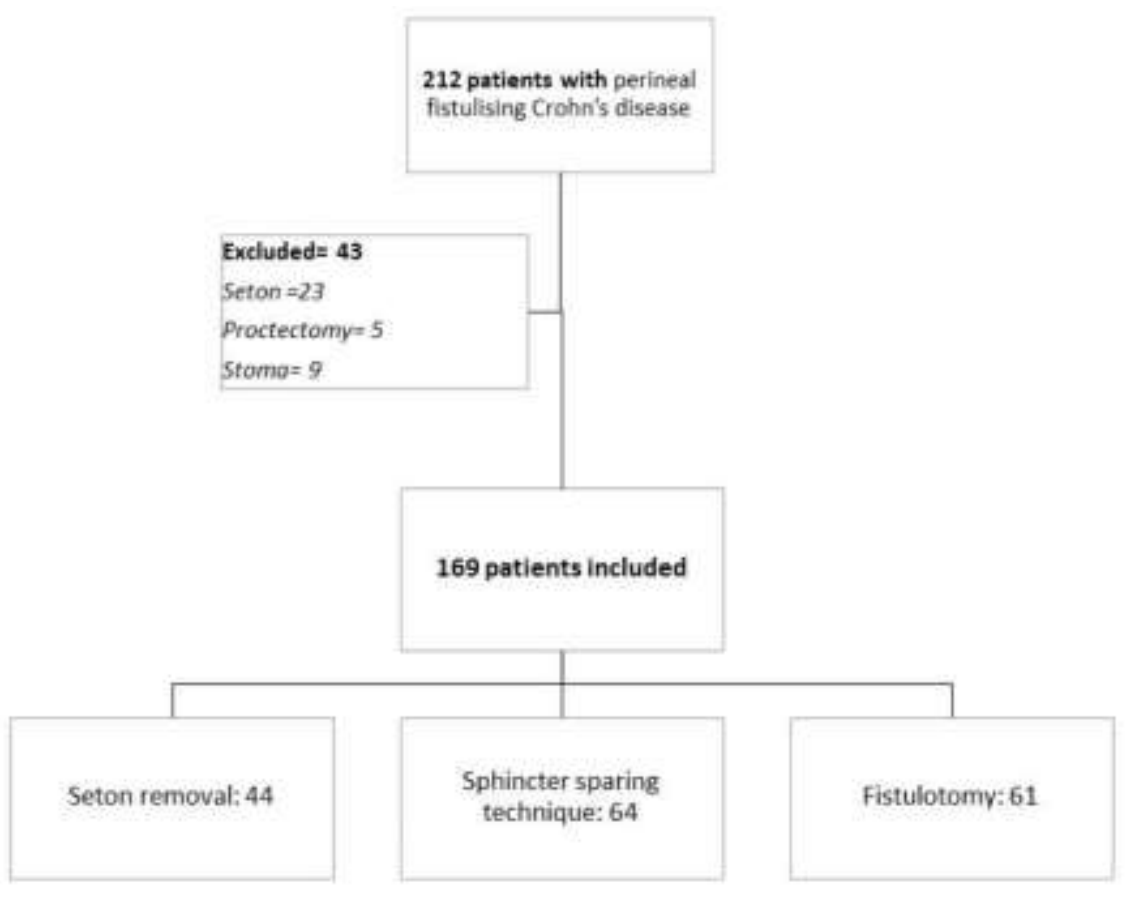


FIGURE 2

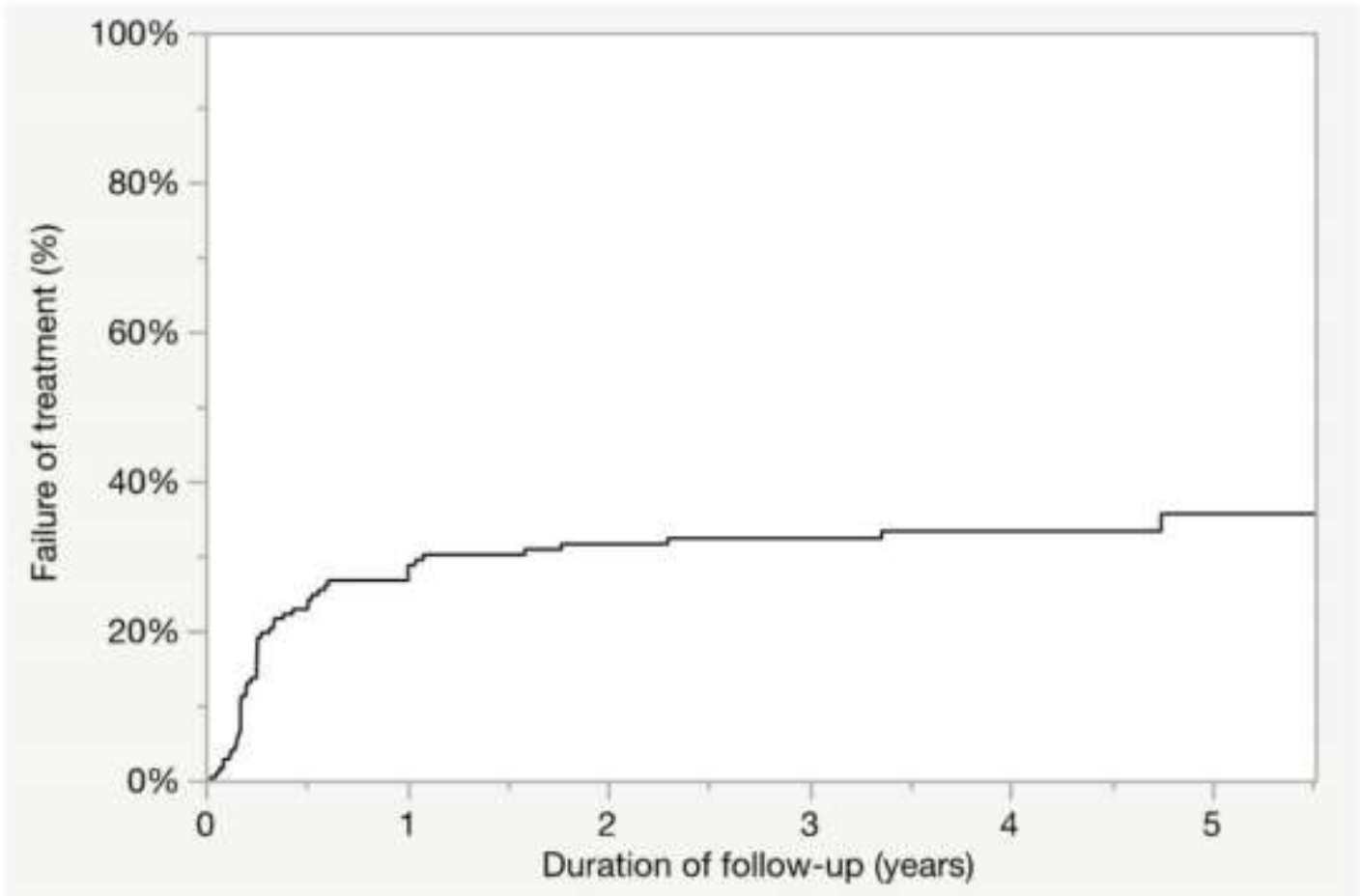

$\begin{array}{lllllll}\text { At risk } & 169 & 107 & 93 & 78 & 64 & 52 \\ \text { N study } & 169 & 131 & 120 & 102 & 84 & 70\end{array}$




\section{FIGURE 3}

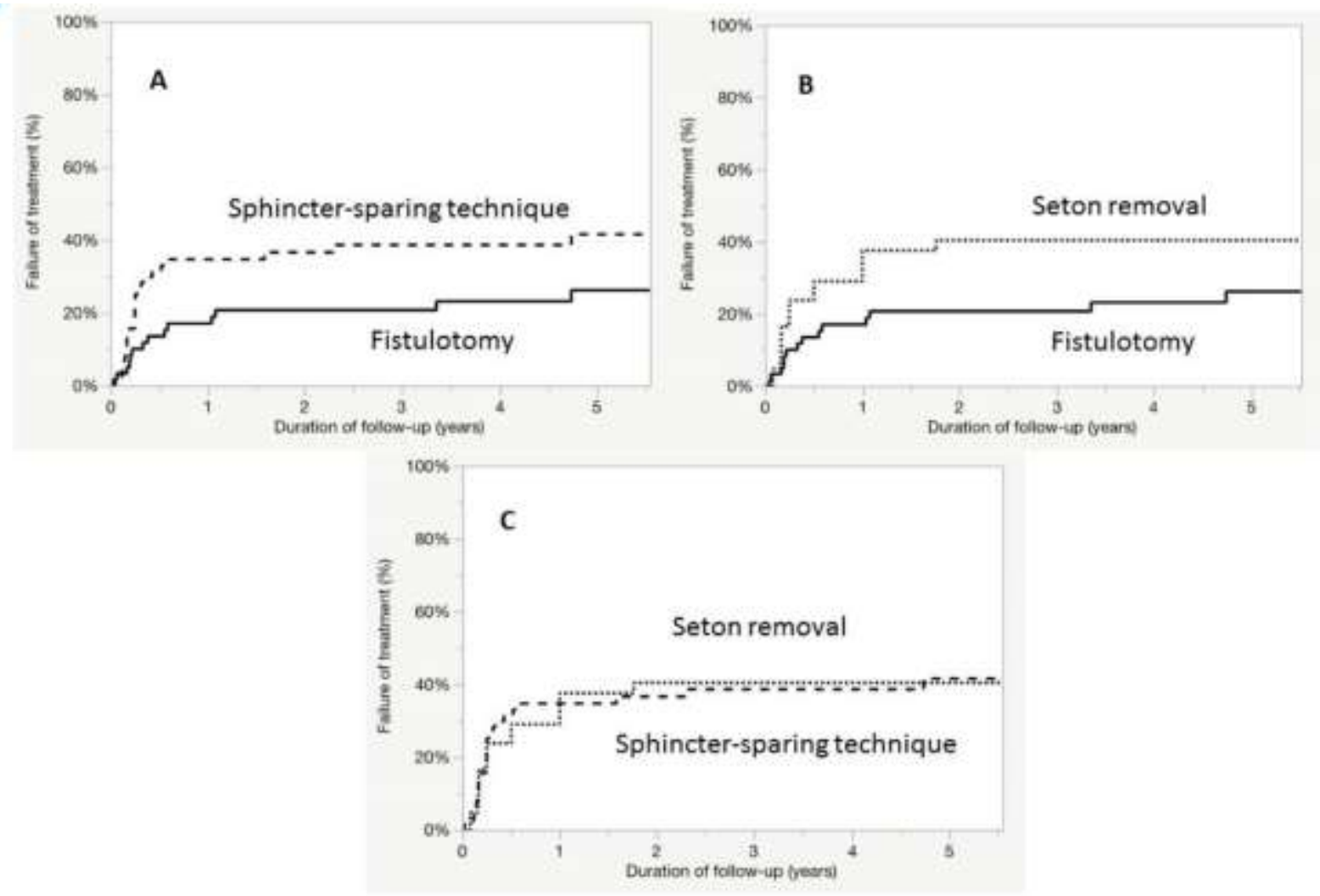

FIGURE 4
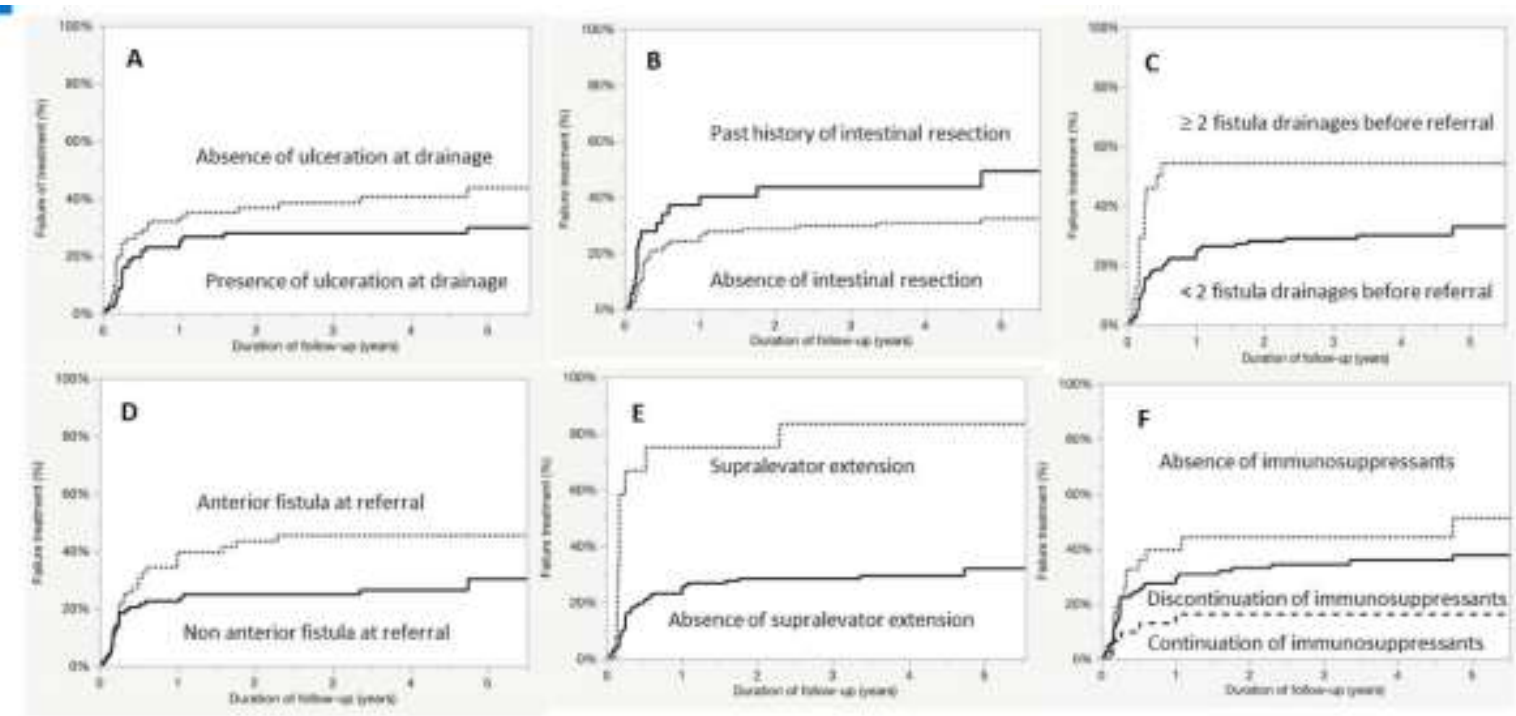